\begin{tabular}{|c|c|c|}
\hline 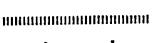 & 型 と & (C) 1986 ISIJ \\
\hline 論 文 & 最適鋳型振動 & \\
\hline
\end{tabular}

\author{
水上 秀昭*.川上 公成 ${ }^{* 2} \cdot$ 北川 融*3 \\ 鈴木 幹雄*3 $\cdot$ 内田 繁孝*4
}

\title{
Lubrication Phenomena in a Mold and Optimum Mold Oscillation Mode in High-speed Casting
}

\author{
Hideaki Mizukami, Kiminari Kawakami, Toru Kitagawa, \\ Mikio SuzukI, Shigetaka Uchida and Yoshimi Komatsu
}

\begin{abstract}
Synopsis:
High speed casting of slabs has become one of the mandatory requirements for improvement of productivity and energy conservation of continuous casting processes. In high-speed casting, however, the lubrication ability of powder between the mold and the solidified shell is deteriorated by increasing casting velocity, and the shell sticking in the mold results in breakout. In order to increase the casting speed, therefore, one of the most important factors is to improve lubrication in the mold.

First, we have carried out quantitative analyses on lubrication phenomena between mold and solidified shell and casting tests with an experimental continuous caster to make in-depth studies on the lubrication mechanism in the mold. Second, based on the results, we have proposed the new concept of mold oscillation for high speed casting.

The results are summarized as follows:

1) Liquid lubrication is dominant at the portion of closely below the meniscus than solid lubrication, and solid lubrication is dominant in the lower portion of the mould.

2) Non-sinusoidal oscillation mode is more effective to reduce the friction force between mold and shell than the conventional sinusoidal one.

By the application of the results of these fundamental studies, Fukuyama No. 5 continuous slab caster has been operating at a maximum casting speed of $2.5 \mathrm{~m} / \mathrm{min}$ without occurrence of breakout, using a non-sinusoidal oscillation mode and powder with a low melting point and low viscosity.
\end{abstract}

\section{1. 緒言}

近年，連続鋳造においては生産性の向上，省エネルギ 一の観点から鋳造速度の高速化が進められている. 日本 鋼管 (株) 福山製鉄所においても，熱鋳片の無加熱直接圧 延を目指して福山 5 号連鋳機が稼動した.

一般に高速化により鋳型と鋳片間の潤滑性能が低下 し，鋳型内で鋳片が拘束される現象（拘束性ブレークア ウト $\left.{ }^{1)}\right)$ が多発することが知られており，鋳型と鋳片間 の潤滑改善対策が高速化のための必要条件となつてい る. 従来は主に潤滑改善対策として, 高速用パウダーの
開発2) 4)が行われてきた。もら一つの重要な因子である 鋳型振動に関して, 日本鋼管(株)では昭和 52 年より鋳 型シミュレーター5)を用い, 鋳型内パウダー消費量にお よぼす鋳型振動条件の影響を調査してきた。しかしなが ら，鋳型と鋳片間の潤滑機構が不明なため, 潤滑改善の ための明確な指針は得られなかつた。

以上のような背景から，本報ではまず第一に鋳型と鋳 片間の潤滑に関して定量的解析を行い， $5 \mathrm{t}$ 試験連鋳機 を用いた鋳造テスト結果とあわせて鋳型内潤滑機構につ いて検討した．次に得られた知見をもとに高速鋳造時の 鋳型と鋳片間の潤滑改善のための最適鋳型振動波形につ

昭和 59 年 4 月 10 月 ·昭和 60 年 4 月本会講演大会にて発表 昭和 60 年 8 月 1 日受付 (Received Aug. $1,1985)$

* 日本鋼管(株) 中央研究所 (Technical Research Center, Nippon Kokan K. K., 1-1 Minamiwatarida-cho Kawasaki-ku Kawasaki 210)

*2 日本鋼管 (株) 中央研究所工博 (Technical Research Center, Nippon Kokan K. K.)

*3 日本鋼管 (株) 中央研究所福山研究所 (Fukuyama Research Laboratories, Technical Research Center, Nippon Kokan K. K.)

*4 日本鋼管 (株) 福山製鉄所 (Fukuyama Works, Nippon Kokan K. K.) 
いて検執した.

\section{2. 鋳型・鋳片間の潤滑機構}

\section{$2 \cdot 1$ 定量的解析および鋳造実験}

\section{$2 \cdot 1 \cdot 1$ 解析手法}

Fig. 1，2 に鉝型と鋳片の間の潤滑状況を示す模式図 および温度分们を示す. 解析モデルの前提として, 鋳型 之鋳片の間にはパウダー層（液体パウダー, 固体パウダ 一）が存在するとした、メニスカスからモールド出口ま でのすべての位䏕において, 液体潤滑と固体潤滑のどち らが支配的になるかを操業条件（鋳造速度, 鋳型振動条 件，ハウダー物性）から計算されるそれぞれの摩擦力の 大小により判定した。ここで液体潤滑とは鋳型と鋳片の 間のすべりが液体パウダー層内で起こることを，末た固 体潤滑とは鋳型と鋳片の間のすべりが鋳型と固体パウダ 一層間で起こることを意味している。

次に計算の手順を示す. Fig. 3 には計算のフローチャ ートを示した.

鋳型と鋳师の間のパウダー膜厚 $d_{f}$ は著者らが先に実 験的に求めた鋳片表而単位面債当たりのパウダー流入量 $Q\left(\mathrm{~kg} / \mathrm{m}^{2}\right)$ と鋳造条件の間の関係式(1) 式5) より (2)

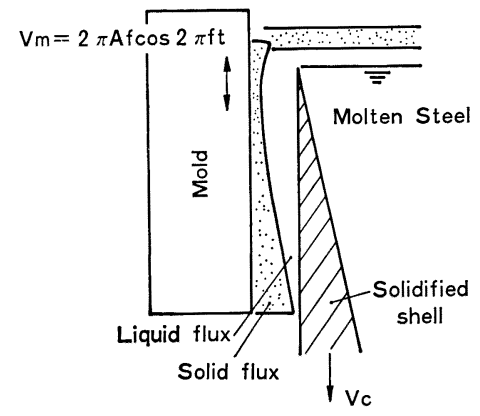

Fig. 1. Schematic view between mold wall and solidified sgell.

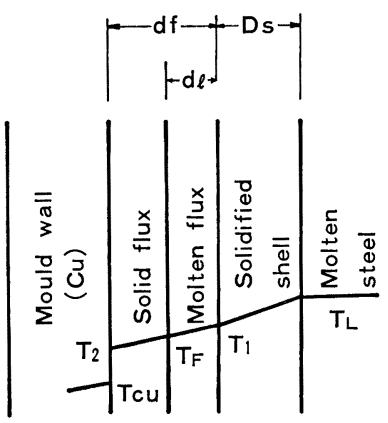

Fig. 2. Temperature distribution between molten steel and copper mold.

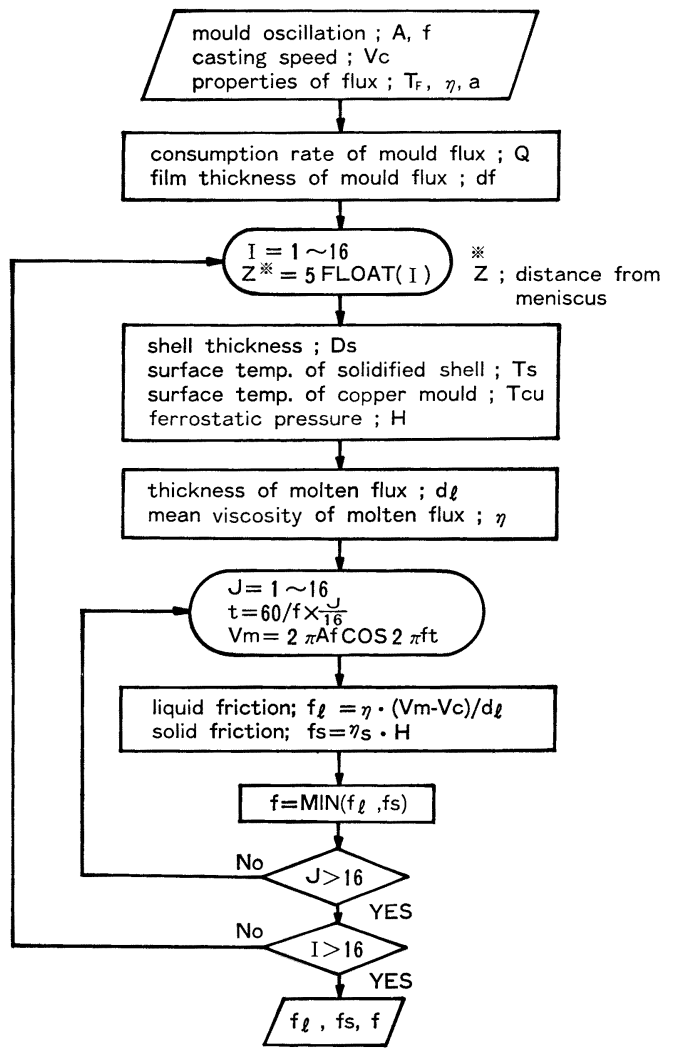

Fig. 3. Flow chart for calculation of friction force.

式で計算した。

$$
\begin{aligned}
& Q=a / V_{c} \cdot \cos ^{-1}\left(-\frac{V_{c}}{2 \pi A f}\right) \\
& d_{f}=Q / \rho_{f} \cdots \cdots \ldots \ldots \ldots \ldots \ldots \ldots \ldots \ldots \ldots \ldots
\end{aligned}
$$

ここで $V_{c}$ は鋳造速度, $A$ は鋳型振動振幅， $f$ は振 動数, $a$ はパウダーの種類により決まる定数, $\rho_{f}$ はパ ウダーの密度である.

次にメニスカスからモールド出口までのすべての位置 に扣いてパウダー層内の温度分布を計算し，その温度分 布からパウダーの溶融厚み $d_{l}$ を求める. 以下にこの手 順を述べる。

鋳型内鋳片の表面温度 $T_{S}$ を(3)式で計算される凝 固シェルの熱抵抗 $R_{S}\left(\mathrm{~cm}^{2} \cdot \mathrm{s} \cdot{ }^{\circ} \mathrm{C} / \mathrm{cal}\right)$ 抌よび鋳型内抜 熱速度 $w\left(\mathrm{cal} / \mathrm{cm}^{2} \cdot \mathrm{s}\right)$ を用いて (4) 式で計算する.

$$
\begin{aligned}
& R_{S}=D_{S} / K_{S} \\
& T_{S}=T_{L}-R_{S} \times w
\end{aligned}
$$

ここで $D_{S}$ は凝固シェル厚， $K_{S}$ はシェルの熱伝導度 $\left(\mathrm{cal} / \mathrm{cm} \cdot \mathrm{s} \cdot{ }^{\circ} \mathrm{C}\right), \quad T_{L}$ は鋼の液相線温度である。また， 鋳型銅板内温度測定結果をもとに鋳型銅板の表面温度 
$T_{\mathrm{Cu}}$ を計算する. パウダー層の鋳片側の温度 $T_{1}$ は $T_{S}$ に等しいと仮定し, 鋳型側の温度 $T_{2}$ は鋳型と固体パウ ダーフィルム間の熱抵抗を考慮して (5)式6)で近似して 求めた.

$$
T_{2}=T_{\mathrm{Cu}}+500
$$

以上のようにして求めた $T_{1}$ および $T_{2}$ さらにはパウダ 一の溶倒温度 $T_{F}$ を用い, パウダー層内の温度分布が 直線的であると仮定して $(6)$ 式で $d_{l}$ を計算した。

$$
d_{l}=d_{f} \cdot \frac{T_{1}-T_{F}}{T_{1}-T_{2}}
$$

単位面積当たりの液体摩擦力 $f_{l}\left(\mathrm{~g} / \mathrm{cm}^{2}\right)$ は $d_{l}$ およ び $T_{F}$ と $T_{1}$ における溶融パウダーの粘性の平均值 $\eta(\mathrm{g} / \mathrm{cm} \cdot \mathrm{s})$ を用いて次式で計算した。

$$
f_{l}=\eta \times \frac{V_{m}-V_{c}}{d_{l}}
$$

なお， $V_{m}$ は $(8)$ 式で示されるので，振動の一周期の 間で $f_{l}$ は鋳型の振動に伴い変化することになる。

$$
V_{m}=2 \pi A f \cos 2 \pi f t
$$

一方, 固体摩擦力 $f_{s}\left(\mathrm{~g} / \mathrm{cm}^{2}\right)$ はパウダー溶融厚 $d_{l}$ および鋳型と鋳片の相対速度 $V_{m}-V_{c}$ に無関係に（9) 式で計算した。

$$
f_{s}=\eta_{s} \times H
$$

ここで， $\eta_{s}$ は鋳型銅板と固体パウダ一間の 固体摩擦 係数であり，前報7) の結果より拉よと 0.25 と仮定し た。また， $H$ は溶鋼静压 $\left(\mathrm{g} / \mathrm{cm}^{2}\right)$ である。

メニスカスから鋳型出口までのすべての位置および振 動の一周期のすべての時刻において $f_{l}$ と $f_{s}$ を比較し, その小さい方の值をもつてその位置，その時刻に拈ける 摩擦力とした。

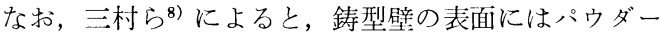
の固着層が存在しており，パウダーはその内側の溶融し ている部分を通して消費されるといらことが報告されて いる。また，K. SORIMACHI ら9) は鋳型と鋳片の間のパ ウダーフィルム内の速度分布，せ九断力分布を解析する 際に $1.5 \mathrm{~mm}$ 2.0 mm のパウダーフィルム厚を仮定し ている．本解析では，パウダーフィルム厚 $d_{f}$ を実際よ り小さく見積もつている危険があるが，現状では操業条 件と固着厚又の関係など不明な点が多いため，前述のよ らな取り扱いを行つた。

\section{$2 \cdot 1 \cdot 2$ 鋳造実験}

$5 \mathrm{t}$ 試験連鋳機を用いて，鋳型と鋳片間の摩擦力を 測 定し，前記解析結果の妥当性について検討した。 $5 \mathrm{t}$ 試 験連鋳機の概略図を Fig. 4 に示した.

装置は 2 本のボールスクリューの同期回転によりダミ ーバーを上下動させる引拔機構と鋳型オシレーション機

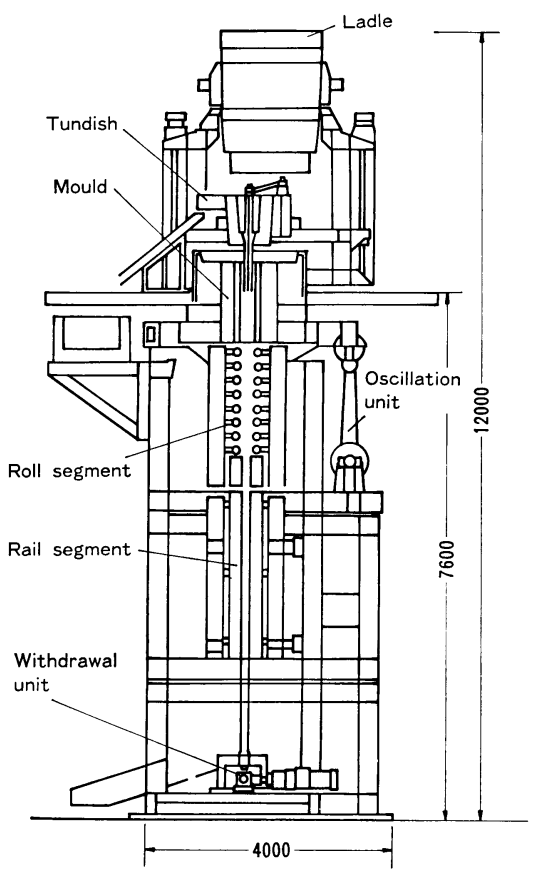

Fig. 4. Schematic view of experimental continuous caster.

Table 1. Major specifications of oscillation unit.

\begin{tabular}{l|l}
\hline Maximum acceleration & $1.0 \mathrm{G}$ \\
\hline Maximum velosity & $6.91 \mathrm{~cm} / \mathrm{s}$ \\
\hline Modification ratio, $\alpha$ & $70 \%$ \\
\hline Reservoir volume & $3000 \mathrm{l}$ \\
\hline Servo valve rated flow & $800 \mathrm{l} / \mathrm{mm}$ \\
\hline Main pump rated pressure & $\begin{array}{l}210 \mathrm{~kg} / \mathrm{cm}^{2} \\
139.5 \mathrm{l} / \mathrm{min}\end{array}$ \\
\hline
\end{tabular}

構を備えている。なお，サイン振動以外の任意の振動波 形を選択できるように，鋳型振動系には電動-油圧サー ボ方式を採用した. Table 1 には油圧振動装置の設備仕 様を示した。鋳型内摩擦力を評価するために，鋳型振動 テーブルと鋳型バックアップフレームの間に取り付けた ロードセルで鋳造中の鋳型振動抗力の变化を測定した. 鋳型と鋳片間の摩擦力の测定はこのようにロードセルに よる鋳型振動抗力の測定を基とした。鋳造時の鋳型振動 抗力は摩擦力と鋳型慣性力の和で表される.したがつて 鋳型振動抗力から慣性力を分離することにより摩擦力を 評価できる10).

試験条件を Table 2 に示した。メニスカスレベルを 変更 (鋳型有効長 ; $750 \mathrm{~mm} \sim 500 \mathrm{~mm}$ ) し，さらに鋳型 パウダーの物性（溶倒温度，粘性）を変えることによ り，液体潤滑領域，固体潤滑領域の占める割合を大幅に 
Table 2. Experimental casting conditions.

\begin{tabular}{l|l|l}
\hline Steel grade & \multicolumn{2}{|l}{$0.06 \% \mathrm{C}$, sheet grade } \\
\hline Casting speed & \multicolumn{2}{|l}{$1.0 \mathrm{~m} / \mathrm{min}$} \\
\hline Oscillation & $\pm 4 \mathrm{~mm}, 100 \mathrm{cpm}$ \\
\hline \multirow{2}{*}{ Mould powder } & A & $T_{F}=1100^{\circ} \mathrm{C}, 3.0$ poise $\left(1300^{\circ} \mathrm{C}\right)$ \\
\cline { 2 - 3 } & C & $T_{F}=850^{\circ} \mathrm{C}, 1.0$ poise $\left(1300^{\circ} \mathrm{C}\right)$ \\
\hline $\begin{array}{l}\text { Mould effective } \\
\text { length }(L)\end{array}$ & $750 \mathrm{~mm}, 500 \mathrm{~mm}$ \\
\hline
\end{tabular}

変化させた。

\section{$2 \cdot 2$ 結 果}

\section{$2 \cdot 2 \cdot 1$ 解析絬果}

Fig. 5 には振動の一周期のうちで $V_{m}$ の絶体値が最 大となる時の液体摩擦力と固体摩擦力の計算值をメ二ス カスからの距離に対して実線で示した。この時の鋳造条 件は図中に示した。 ハウダーAの特性は Table 2 中に示 した、振動の一塥期のらちで $f_{l}$ は $V_{m}=2 \pi A f$ の線(A) と $V_{m}=-2 \pi A f$ の線(B)の間を動くことになり, $V_{m}=V_{c}$ となる時 $f_{l}=0$ となる. したがつて $f_{l}=f_{s}$ となる位置 $Z_{0}$ は振動の一夙期に打いて時々刻々変化している。図 より，メニスカス直下では $V_{m}$ の絶対值が最大, すな わち $f_{l}$ が最大の場合でも $f_{l}<f_{s}$ となり液体潤滑が支配 的となつている. また $V_{m}$ の絶対值が最大の時, 鋳型下 部においては逆に $f_{s}<f_{l}$ となり固体潤滑が支配的とな つている.

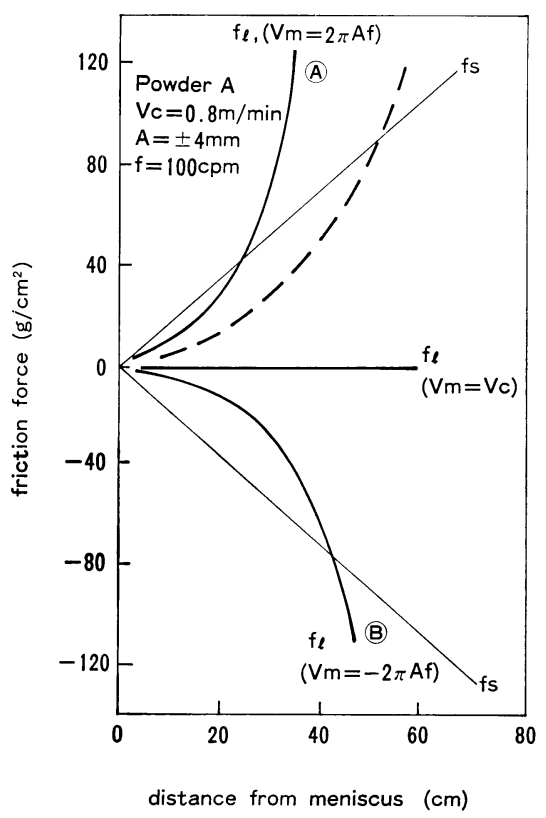

Fig. 5. Distribution of liquid friction force and solid friction force in the mold.

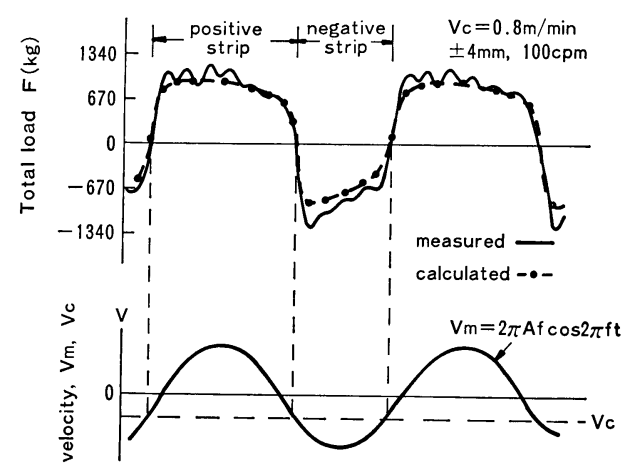

Fig. 6. Comparison between measured and calculated friction force.

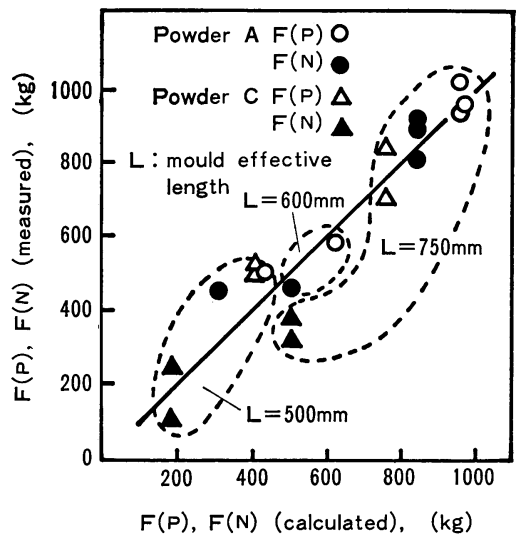

$F(N)$ : Maximum friction force at negative strip period $F(P)$ : Maximum friction force at positive strip period Fig. 7. Comparison between measured and calculated friction force.

\section{$2 \cdot 2 \cdot 2$ 鋳造実験結果}

Fig. 6 にはロードセルで測定された振動一周期の鋳 型振動抗力変化を示した. 併せて, 鋳型と鋳片間の摩擦 力の計算值と鋳型慣性力の計算值の和を破線で示した. 振動一周期のらちの鋳型振動抗力変化について, 実測值 と計算值とは良く一致している. Fig. 7 にはポジティ ブストリップ時, ネガティブストリップ時の最大摩擦力 $\left(V_{m}\right.$ が最大の時) の実測值と本解析による計算値を比較 して示した。図より両者は良く一致した。なお，図中鋳 型と鋳片間の摩擦力の計算值 $F(P), F(N)$ は $2 \cdot 1$ 項で 示した単位面積当たりの摩擦力 $f\left(\mathrm{~g} / \mathrm{cm}^{2}\right)$ の鋳型内積分 値である。

\section{$2 \cdot 3$ 考 察}

$2 \cdot 3 \cdot 1$ 鋳型・鋳片間の潤滑機構

以上, 今回の解析モデルにより, 鋳型内で発生する摩 擦力を十分推定できることが確認できた．以下にこのモ 
デルをもとに鋳型内の潤滑機構について検討する.

前述の Fig. 5 から, メニスカス直下に拈いては， $V_{m}$ の大小によらず液体潤滑が支配的であり，また鋳型下部 においては $V_{m}$ が大きい時に固体潤滑が支配的になるこ とがわかる、また，ネガティブストリップ時はポジティ ブストリップ時より鋳型と鋳片間の相対速度が小さいた め (7) 式で計算される $f_{l}$ は小さくなり，鋳型上部の液 体潤滑領域は増加する. Fig. 5 中には点線でパウダー を変更 (Table 2 中の G) した時のポジティブストリッ プ時の液体摩擦力の最大值を示した. 溶倒温度が低く, 粘性が低いハウダーCの方が ( 7 ) 式に沶いて $d_{l}$ が大き く，クが小さくなるため液体摩擦力は小さくなり，した がつて, この場合も鋳型上部の液体澗滑領域は増加す る.

以上のように鋳型内の潤滑機構はメニスカスからの距 離, 操業条件 (鋳造速度, 鋳型振動条件, パウダー種) により変化し，また振動の一周期内に拈いても時々刻々 変化する、しかしながら, 鋳型上部のメニスカス直下に おいては $V_{m}$ の大小によらず，また他の操業条件によら ず液体潤滑が支配的となり，一方鋳型下部においては $V_{m}$ が大きい場合や使用するパウダーの粘性が大きく溶 倒温度が高い場合に固体潤滑が支配的になることが推定 される。

鋳型と鋳片間の潤滑に関する報告の中で，大宮ら ${ }^{10)}$ は 鋳型の振動解析から液体潤滑が支配的と報告している. 中森ら ${ }^{11)}$ は鋳型と鋳片間には液体摩擦と固体摩擦が共存 するが，液体摩擦がより支配的であると報告している. また，M. W W OLF $^{12)}$ は鋳型と鋳片間の摩擦力測定結果か ら，ポジティブストリップ時には固体摩擦が, ネガティ ブストリップ時には液体摩擦が支配的と報告している. さらに, $P . V$. Riboud ら ${ }^{6)}$ はビレット連鋳における鋳 造後の鋳型内面に残存するパウダ一の観察結果から, メ ニスカス直下では液体潤滑が，また鋳型下部では固体潤 滑が支配的と類推している.これらの種々の測定・観察 結果は上述したようにすべて今回の解析モデルにより定 性的に矛盾なく説明できる。

A) Reduction of tensile force, $F_{\ell}$

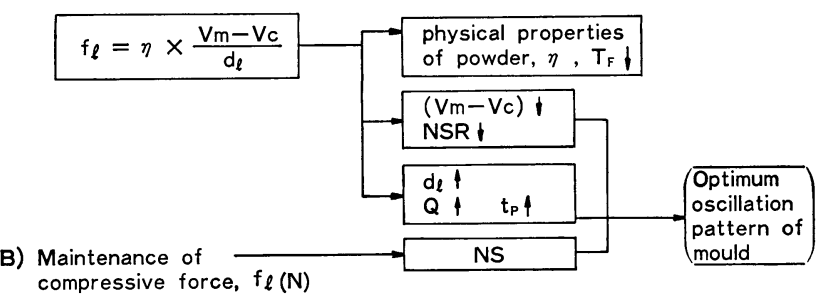

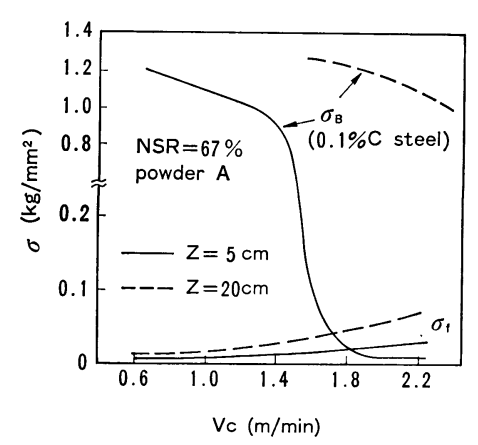

Fig. 8. Comparison between tensile stress and high temperature strength of steel.

\section{$2 \cdot 3 \cdot 2$ 高速鋳造時の最適鋳型振動波形}

以上得られた知見に基づき，高速鋳造特の最適鋳型振 動波形について検討した.

鋳片にかかる引張応力 $\sigma_{f}$ を，摩擦力および㠜固シェ 儿厚 $D_{S}$ を用いて $(10)$ 式で計算し，鋳版の高温強度 ${ }^{13)}$ $\sigma_{B}$ と比較して Fig. 8 に示した.

$$
\sigma_{f}=\int_{0}^{z} f d Z / D_{S}
$$

なお，(10)式で $z$ はメニスカスからの距離， $f$ は位置 $Z$ に打ける単位面樍当たりの摩擦力であり, 液体摩擦力 $f_{l}$ 之固体摩擦力 $f_{s}$ の小さい方の值である. Table 2 中 のパウダーAを用い, NSR (ネガティブストリップ時間 比率 $)=67 \%$ の振動条件の下で，一例としてメニスカス から $5 \mathrm{~cm}$ と $20 \mathrm{~cm}$ の位置について検討した. $Z=5 \mathrm{~cm}$ の位置では $V_{c} \approx 1.8 \mathrm{~m} / \mathrm{min}$ で $\sigma_{f}>\sigma_{B}$ となりシェル破 断の危険がある. 一方, $Z=20 \mathrm{~cm}$ の位置では $V_{c}=2.2$ $\mathrm{m} / \mathrm{min}$ においても $\sigma_{f}<\sigma_{B}$ でありシェル破断の可能性 が少ないことが定性的にわかる.したがつてシェル破断 すなわち拘束性ブレークアウトを防ぐにはメニスカス直 下に注目して，この部分の脆弱なシェルを安定して引き 拔くための振動条件を見出せばよいことが推論される.

Fig. 9 には高速鋳造時の最適鋳型振動波形導出の過 程を示した. 高速鋳造時にメニスカス直下の脆弱なシェ ルを安定して引き抜くには次の二つの条件を満足するこ

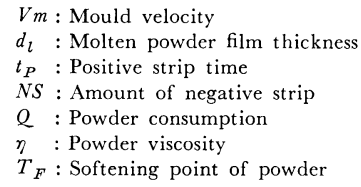

Fig. 9. Process of determination of optimum mold oscillation mode. 
とが必要であると考えた。

（1）シェルに対する引張力の低減

(2) シェルに対する圧縮力の確保

（1）の条件を満たす其体的な項目としては，メニスカス 直下で支配的な液体摩擦力を表す前述の（7) 式によれば 下記の三つが挙げられる。

（i） 溶倒温度 $T_{F}$ および粘性 $\eta$ の低いパウダーの 使用

(ii) 鋳型と鋳片閐の 相対速度 $V_{m}-V_{c}$ の 遅い鋳型 振動

(iii） パウダー流入舅 Q を増やすための低ネガティ ブストリッブ操業 (( 1 ) 式より)

(ii)，(iii)はサイン振動においては，ともにネガティ ブストリッブ辝をトげることにつながる。また（i )につ いて，川本鋼管 (株) 福山 5 号連鋳機においてはリチウム 入りの低粘性・低軟化点ハウダーを開発4) して操業に使 用している.

一方 ( 2 )に対しては, JUNGHANS の提案以来多くの研 究者 ${ }^{14) 15)}$ により, 安定鋳造にはメニスカス直下の脆弱な シェルに生縮力を加えながら引き抜くことが必要とされ ている，著者ら 性鋳に圧縮力をか恀るにはある程度 のネガティブストリッブを振動条件として確保すること が必要であることを確認している。ネガティブストリッ プを表す指標として，ネガティブストリップ時間比率や 速度比深があるが，ここでは両者を組及合わせた(11) 式 で表されるネガティブストリップ量 $(N S)$ を考慮した。

$$
N S=\int_{t_{1}}^{t_{2}}\left(V_{m}-V_{c}\right) d t
$$

ここで $t_{1}, t_{2}$ は $V_{m}=V_{c}$ となる時刻である. $N S$ を 大きくするにはネガティブストリップ時の $V_{m}-V_{c}$ を

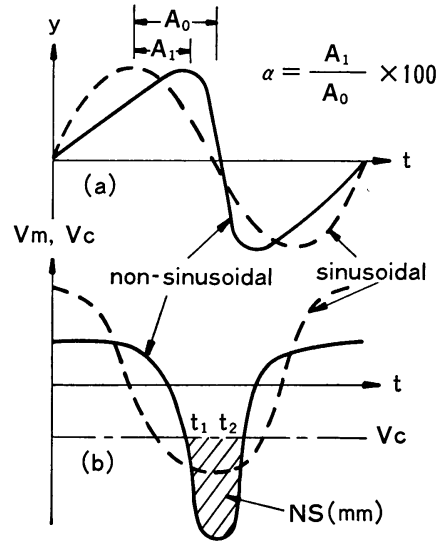

Fig. 10. Schematic diagram of non-sinusoidal oscillation mode.

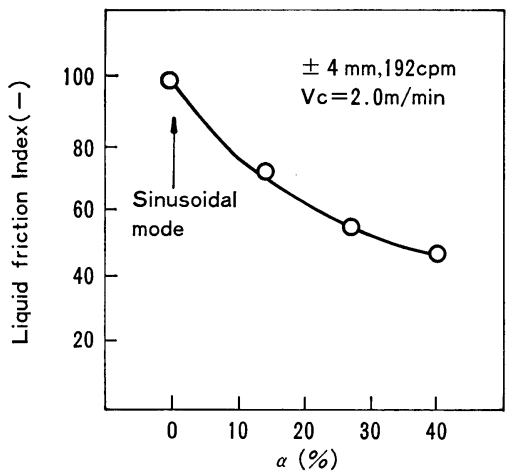

Fig. 11. Effect of non-sinusoidal oscillation mode on liquid friction force.

大きくすればよいことがわかる。

以上の (1), (2) を同時に満足するには，従来のサイ ン振動に代わり，Fig. 10 に示すよらな鋳型の上昇時間 を下降時間より長くするようにサイン振動を偏倚させた 波形（以後この波形を非サイン偏倚波形と呼ぶ）でなけ ればならない。またこのよらな波形を容易に実現する ためには，鋳型の振動加速度，振動速度を大きくできる 電動-油灰サーボ方式の振動系が必要である.

Fig. 11 にはメニスカス直下のポジティブストリップ 期における液体摩擦力におよぼす非サイン偏倚波形の効 果を(7)式を用いて計算した結果を示した。非サイン 偏倚波形にすることによりポジティブストリップ期の $\left(V_{m}-V_{c}\right)$ が減少し，かつ $t_{p}$ 時閒の増大により $d_{l}$ が 増加するために $f_{l}$ が低下するが，その減少割合をサイ ン振動に対して比較した。図中波形歪交 $\alpha$ は $\alpha=A_{1} /$ $A_{0} \times 100 \%$ で定義した. $40 \%$ の波形歪み率で液体摩擦 力は約 $40 \%$ 減少することが予想された。この $40 \%$ の 減少分の過半を占める約 $30 \%$ 分は鋳型上昇速度の低下 により鋳型と鋳片の相対速度が下がることによる効果で あり，残りの $10 \%$ 分は非サイン偏倚波形によりポジテ ィブストリップ時間 $t_{P}$ が増大してパウダー流入量が増 えることによるものである。

一方，シェルにかかる圧縮力については Fig. 10 に 示すように非サイン偏倚波形ではネガティブストリップ 時間は短いが，鋳型下降速度が大きいために $(10)$ 式で示 されるネガティブストリップ量はサイン振動と同等もし くはそれ以上の值を確保できることが示される。

\section{3. 非サイン偏倚波形による鋳造}

\section{$3 \cdot 15 \mathbf{t}$ 試験連鋳機による効果確認試験}

次に $5 \mathrm{t}$ 試験連鋳機を用いて鋳型と鋳片間の摩擦力を 
実測することにより，非サイン偏倚波形の効果を実験的 に確認した結果を述べる. Table 2 の鋳造条件で波形の 歪み率は最大 $50 \%$ まで変化させた。

潤滑性におよぼす非サイン偏倚波形の効果は液体潤滑 領域で発揮される。したがつて鋳型下部に固体潤滑領域 が存在すると，ロードセルで測定する摩擦力は Total の摩擦力として固体摩擦力も含めて測定してしまらため に, 固体摩擦がノイズとなつて, 非サイン偏倚波形の効 果を実際に確認できない場合が生ずる，それゆ觉験的 に検出可能とするため, 低粘性, 低軟化点パウダーCを用 い,メニスカスレベルを通常レベルより $250 \mathrm{~mm}$ 下げて 鋳型の有効長を $500 \mathrm{~mm}$ (通常は $750 \mathrm{~mm}$ ) とし, Total の摩擦力のらち固体摩擦力を大幅に低下させて液体摩擦 力の占める割合を増加させた試験を行つた：この条件で はほぼ $100 \%$ 液体潤滑となることが計算結果から推定さ れる (Fig. 12)。

鋳造中に鋳型振動モードをサイン振動から非サイン偏 倚波形に変更した時の摩擦力の变化を Fig. 13 K示し た. 非サイン偏倚波形にすることにより摩擦力は 20〜 $30 \%$ 減少している. 非サイン偏倚波形の効果 $40 \%$ のう ちの約 7 割は $V_{m}-V_{c}$ の減少に, また残りの 3 割はパ ウダー流入量の増加によることを $2 \cdot 3 \cdot 2$ で示した．振動 モードを変更した時に鋳型と鋳片間の溶融パウダーフィ

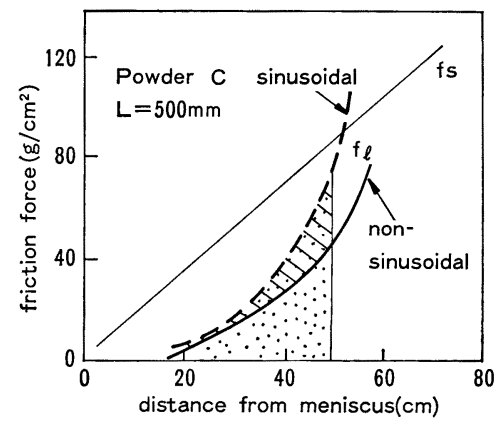

Powder; C, Mold effective length; $500 \mathrm{~mm}$

Fig. 12. Distribution of friction force.

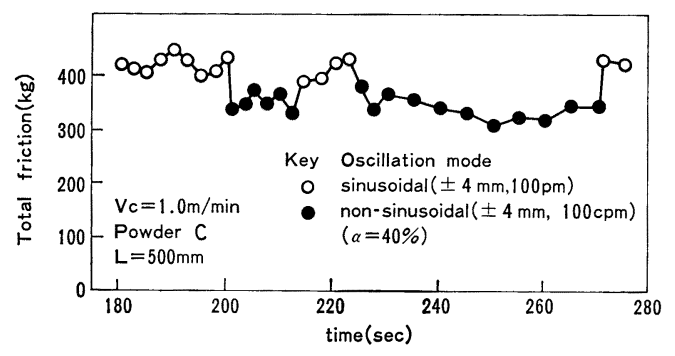

Fig. 13. Change in friction force during casting.

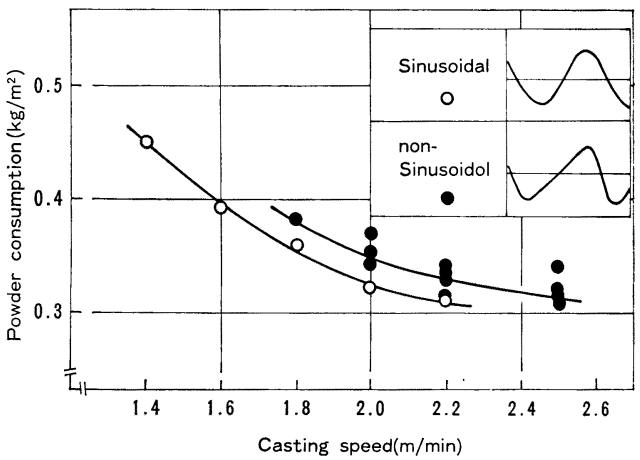

Fig. 14. Effect of non-sinusoidal oscillation mode on powder consumption rate.

ルム厚が瞬時には定常状態にならない8) ため，本実験で は $V_{m}-V_{c}$ の効果すなわり摩擦力としては 2 - 3 割の減 少が確認でさたことが示されている.

\section{$3 \cdot 2$ 非サイン偏倚波形の実機への適用}

以上述べたよらに，5t 試験連鋳機を用いて非サイン 偏倚波形による鋳型と鋳片間の摩擦力低減㕮果を確認し た。

高速スラブ連鋳機への適用の可能性を確認する目的で 京浜 2 号連鋳機を使用して，パウダーの流れ込み量の確 認と鋳造安定性，鋳片表面性状に及ぼす影響を調査し た ${ }^{16)}$.これらの結果をもとに，福山 5 号大型スラブ連鋳 機では，非サイン偏倚波形を用いることにより，最高 $2.5 \mathrm{~m} / \mathrm{min}$ までの高速鋳造を安定して来施している. $2.5 \mathrm{~m} / \mathrm{min}$ までにおけるパウダー流入量に拈よぽす非 サイン偏倚波形の効果を Fig. 14 に示した。鋳造速度 $2.0 \mathrm{~m} / \mathrm{min}$ 以上の高速鋳造に拈いても, 波形歪又率 40 \% の非サイン偏倚波形により，流入量は約 $10 \%$ 増加 していることが示されている。また，シェルにかかる引 張力低減効果の確認を, 鋳型振動装狊の油圧シリンダー にかかる压力を測定し，鋳造中と空運転時の差を用いて 評価した。 $2.0 \mathrm{~m} / \mathrm{min}$ を越える高速鋳造時に执いても 非サイン偏倚波形により鋳型と鋳片間の摩擦力が低下す ることが確認できた17).

\section{4. 結}

論

大型スラブ連鋳における鋳型と鋳片間の潤滑に関して の定量的解析および $5 \mathrm{t}$ 試験連鋳機を用いた鋳造テスト 結果の解析から，鋳型内の潤滑機構を解明し，メニスカ ス直下に拈いては液体潤滑が，また鋳型下部に扣いては $V_{m}$ が大きい場合や使用するパウダーの粘性が大きく溶 倒温度が高い場合に固体潤滑が支配的になることを明確 にした．以上の知見をもとに高速鋳造時の最適鋳型振動 
波形について検討し，従来のサイン振動にかえて鋳型の 上昇時間を下降時間より長くするよらな非サイン偏倚波 形が, メニスカス直下の引張摩擦力の低減, 脆弱なシェ ルに対する化縮力の確保の 2 点から有効であることが確 認できた。

これらの基礎研究の結果に基づき, 福山 5 号スラブ連 鋳機では非サイン偏倚波形を用いることにより，最高 $2.5 \mathrm{~m} / \mathrm{min}$ までの高速鋳造を安定して実施している.

終わりにあたり $5 \mathrm{t}$ 試駼連鋳機の設計・製作に御尽力 いただいた設備部製鋼チームの長谷部信久氏，川田 浩 氏，庄田順一氏に謝意を表します。

\section{文献}

1) 系山誓刊, 垣生泰弘, 反町健一, 川原田昭, 矢 部 直：鉄と鋼，68 (1982), p. 784

2) 中野武人：学振 140 委, 「鋼の連鋳用パウダーの 物性と鋳片性状シンポジウム」(昭和 59 年 12 月)

3) 中户 参, 野崎 姼, 垣生泰弘: 学振 140 委, 「鋼の連鋳用パウダーの物性と鋳片性状シンポジ ウム」(昭和 59 年 12 月)

4 ) 宮脇芳治, 半明正之, 内出繁孝, 寺阙卓治, 白谷 勇介，石田寿秋：鉄々鋼，70 (1984)，S 143

5 ) 川上:公成, 北川融, 水上秀昭, 内堀秀男, 宮原 忍，鈴木幹雄，白谷勇介：鉄と鋼，67 (1981), p. 1190

$6)$ P. $V$. Riboud and $M$. Larrece: NOH-BOSC Proceedings, Detroit, 62 (1979), p. 78

7 ) 小松政美, 北川 融, 川上公成: 鉄と鋼, 68 (1982), S 927

8 ) 三村義人, 山口福吉, 高橋隆治, 荻林成章, 山口 紘一，小山邦夫：鉄と鋼， 70 (1984), S 146

$9) K$. Sorimaghi, $H$. Yamanaka, $M$. Kuga, $H$. Shikata and $M$. Saigusa: Engineering Foundation Conferences, Henniker (1983)

10) 大喜茂, 中户参, 坦生泰弘, 汇見俊彦, 浜上 和久，馬田一，福原涉：鉄と鋼, 68 (1982), S 926

11) 中森幸雄, 藤䜿洋一, 常盤慧可, 片阙冬里, 常阔 䐋，三隅秀幸：鉄と鋼，70 (1984), p. 278

12) $M$. Wolf: Electric Furnace Conference Proceedings, Kansas City, 40 (1982), p. 335

13) 水上秀炤, 村上勝彦, 北川融, 川和高穂, 宮卜 芳雄：鉄と鋼, 64 (1978), S 149

14) J. Savage and W. H. Pritchard: JISI, 178 (1954), p. 269

15) I. M. D. Halliday: JISI, 191 (1959), p. 121

16) 半明正之, 山上毫, 宮野治天, 有賀勉, 高野 秀一, 内田繁孝, 水上秀昭: 鉄之鋼, 71 (1985), S 249

17) 鈴木幹雄, 北川融, 内田繁孝, 政阙俊雄, 小澤 宏一，森 孝志：鉄と鋼，71 (1985), S 1026 